\title{
Government debt management at low interest rates $^{1}$
}

Debt management can be used at low interest rates to lower bond yields, to provide bank assets and thereby help maintain broad money growth, or to save on interest payments. The US example in the 1930s and the recent Japanese case suggest that this tool was not fully exploited in either case.

JEL classification: E50, E51, E52, E58, E60, E61, E63, E65, H63.

The advisability of central banks' extraordinary buying of government bonds is much debated. However, the question of how treasury debt management can contribute to maintaining the growth of bank assets, lowering long-term government bond yields or reducing net government interest payments is rarely posed. The Bank of England's and Federal Reserve's March 2009 announcements of outright purchases of gilts and Treasury bonds drew more attention than the respective treasuries' announcements of large issues of bonds around the same time. Inattention to debt management in the context of proposals to alter the duration of government debt in private hands is puzzling. After all, the government balance sheet tends to bulk large in relation to that of the central bank. As a result, a substantial change in the central bank's assets can be offset by a small change in government liabilities.

This feature first discusses the objectives of debt management and monetary policy and the complementarities and tensions between them, especially at low interest rates. It then reviews the interaction of central bank purchases of government bonds and debt management in the United States in the 1930s and Japan in the last 10 years. A discussion of recent initiatives in the United Kingdom, Japan and the United States follows.

\section{Interactions between debt management and monetary policy}

A government with sizeable financial obligations must choose its debt composition: fixed-rate or short-term/variable rate; domestic or foreign

The authors thank Naohiko Baba, Claudio Borio, Brendan Brown, Michael Cross, Jacob Gyntelberg, Richard Koo, Kenneth Kuttner, Hiroshi Nakaso, Akira Otani and Frank Packer for discussions, and Jhuvesh Sobrun for assistance. Any errors remain those of the authors. Authors' views are not necessarily shared by the Bank for International Settlements. 
currency; nominal or price-indexed. These choices comprise debt management. Nowadays, debt management generally aims to minimise cost, to limit variability of interest payments and bunching of cash flows, to offset variation in taxes and spending, or to achieve some combination of these. Not so long ago, debt management was given a role in stabilising the economy, alongside, or even as a part of, monetary policy.

Monetary policy seeks to stabilise prices and economic activity by influencing spending by firms and households. When activity strains an economy's capacity, policy restrains spending. When activity falls short, policy attempts to stimulate spending. In many countries, monetary policy had come to focus on hitting an inflation objective by setting a short-term interest rate.

The goals and conduct of debt management and monetary policy can complement each other, but can also give rise to tensions. The traditional view was that the cost of debt service was secondary to the need to "fund" the debt, that is, to issue fixed-rate debt so long-dated that banks would not hold it (or it would not serve as near money for non-banks). Structurally, skilful debt management aids monetary policy in producing a deep, liquid and resilient market for operations. However, debt management aimed only to minimise costs might create tensions with monetary policy by relying on short-term debt (given the normal upward slope of the yield curve). Over the business cycle, debt management can "get in the way" of monetary policy, for instance, if bonds are issued heavily when the central bank is easing.

The scope for interaction and even tensions depends on how the economy works and how monetary and debt management policies are implemented. In terms of the economy's functioning, this scope is minimal if the mix of bills and bonds does not matter for the shape of the yield curve or the economy at large. Private investors may treat treasury bills and bonds as perfect substitutes, pricing bonds as an average of expected bill yields over the bond's life. In this case, the mix of bills and bonds will not affect yields. ${ }^{2}$ For the scope for interaction to be minimal, debt composition must also not affect firm and household spending through its effect on broad money (Box 1).

Until recently, the way monetary and debt management policies were implemented had narrowed the scope for their interaction. As noted, monetary policy entailed setting the overnight interest rate in response to inflation and growth forecasts. Though details differed, central banks operated at the short end in secondary markets or against collateral and thus left the mix of government bills and bonds in private hands unaffected. In this sense, monetary policy left debt management policy to the debt manager. For their part, debt managers had generally opted to "regularise" debt by issuing steadily and predictably to minimise costs (Garbade (2007)). Such debt management hardly enters into the central bank's forecast.

2 For a recent discussion of the case of perfect substitutability, see Clouse et al (2003), and the evidence in Baba et al (2005) and Oda and Ueda (2007). For imperfect substitutability, see Bernanke et al (2004) and Kuttner (2006).

The interaction of debt management and monetary policy ...
... depends on how the economy works and how the policies are implemented 


\section{Box 1: Bond buying and debt management: a quantitative view}

Following Congdon (2003), this box simplifies the economy's balance sheet to show the quantitative differences among various operations that can be carried out at very low interest rates. The upshot is that a central bank's purchase of government bonds can be seen as a compound of quantitative easing, defined as the central bank injecting funds into the banking system, and a debt management exchange of treasury bills for treasury bonds. This graphical "T-account" exercise is consistent with King's (2009) emphasis on the purchase of gilts from the "wider economy", and not just banks, as well as the Bank of England's purchase of gilts of five to 25 years' residual maturity, usually held by non-banks.

In the initial situation (Graph A, top left-hand panel), the government has a mix of bill and bond liabilities. The bills are held by the central bank and the commercial banking system. The non-bank private sector holds bonds and deposits in the banking system. Cash holdings are abstracted away, so that bank deposits comprise the stock of money. The corporate and household sectors as borrowers from banks and issuers of bonds are also abstracted away.

\section{Stylised monetary and debt management policy}

Initial situation

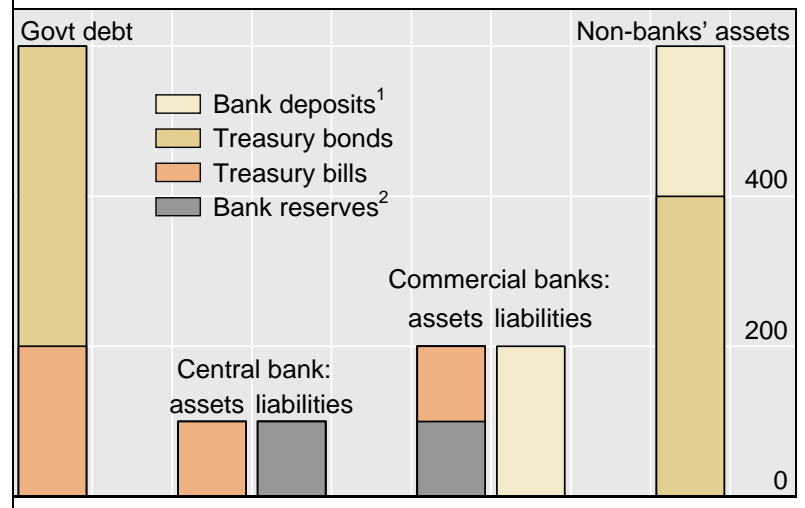

Debt management: bills swapped for bonds ${ }^{4}$

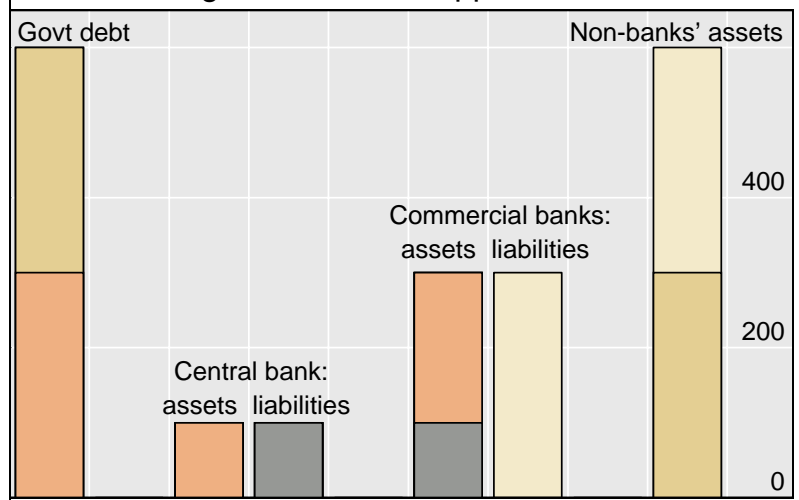

Quantitative easing: central bank buys bills ${ }^{3}$

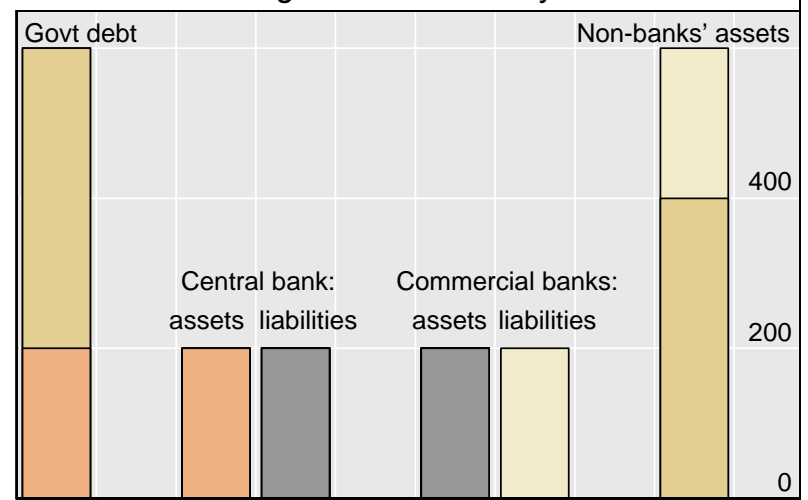

Central bank buys bonds

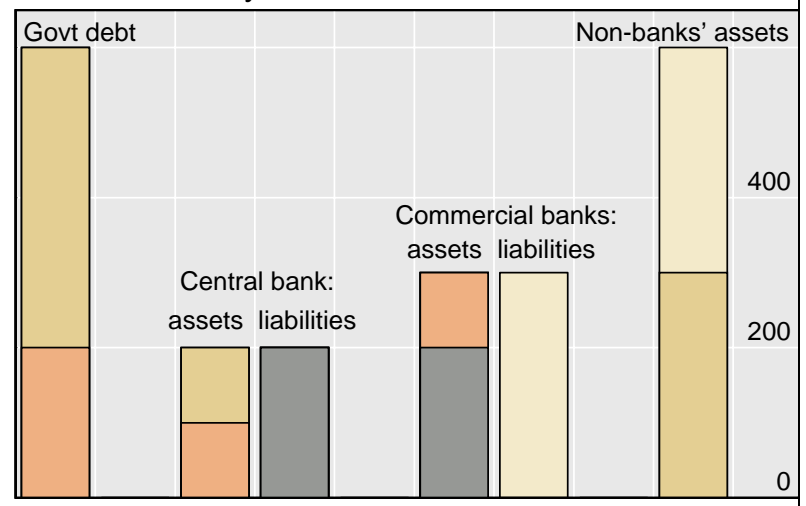

1 Held by the private sector. ${ }^{2}$ Commercial banks' deposits with central bank. ${ }^{3}$ The central bank buys 100 bills from commercial banks. Their cash reserves increase by 100. ${ }^{4}$ The government sells 100 in bills to the commercial banks and buys 100 in bonds.

Sources: Congdon (2003); authors' calculations.

Graph A

In this simple schema, one can represent quantitative easing as an operation between the central bank and the commercial banking system (Graph A, upper right-hand panel). The central bank buys treasury bills with its liabilities, and bank reserves increase. Not much happens: the banks hold fewer treasury bills paying essentially no interest but more similarly unremunerative bank reserves. This simplifies the Bank of Japan's operations, which used a wide set of instruments and counterparties, and the range of holders of bank reserves (which included holdings of foreign banks that had swapped dollars for yen), but it captures the disconnect between rapid growth of bank reserves and muted growth of the money supply that was observed in Japan. 
A debt management operation can in principle have greater effect, at least in this simple financial system (Graph A, bottom left-hand panel). The Treasury sells bills to commercial banks and buys bonds from non-bank investors with the proceeds. The non-bank private sector holds less risky treasury bonds and more bank deposits (more money). (Bank reserves are assumed to be a non-binding constraint.)

A central bank that buys treasury bonds basically combines these two operations (bottom right-hand panel). The central bank credits the bank of the seller of the bond with bank reserves, and the bank credits the non-bank investor with a deposit. Money holdings increase, as with the debt swap of bills for bonds, but banks hold more excess bank reserves rather than bills.

In the real world, the results in this simplified financial system may not follow through. The non-bank private sector has in fact borrowed from the commercial banks. Thus, purchases of government bonds by the government or central bank might finance non-banks' repayment of such bank debt rather than boosting broad money (UK House of Commons (2009)). (In particular, an institutional investor might sell a government bond and purchase a newly issued corporate bond, and the issuer might repay a bank loan.) Finally, even if broad money can be increased, it is not clear that would necessarily increase spending by firms and households.

There is some mapping between institutional arrangements and the interactions of the two policies. A generation ago, the Bank of England and the Reserve Bank of India both served their governments as debt managers, consistent with a concept of monetary policy as embracing debt management. Subsequently, as the Bank of England focused on inflation targeting through short-term rate setting, debt management was moved to a separate dedicated office (Bleijer (1999)). Many governments in the euro area have also set up debt management offices (Kalderen and Blommestein (2002)), given Eurosystem monetary operations that advance against broad collateral rather than buying government debt outright. In the United States, where the central bank's mission remained broader, the Treasury and the Federal Reserve have continued to cooperate in debt management as principal and agent.

The scope for interaction between monetary policy and debt management today has widened. In part, this is due to the tide of opinion, which has been running against the view that bond yields approximate the average of future

\section{BoE and Fed buyback announcements: 10-year government bond yields}

In per cent

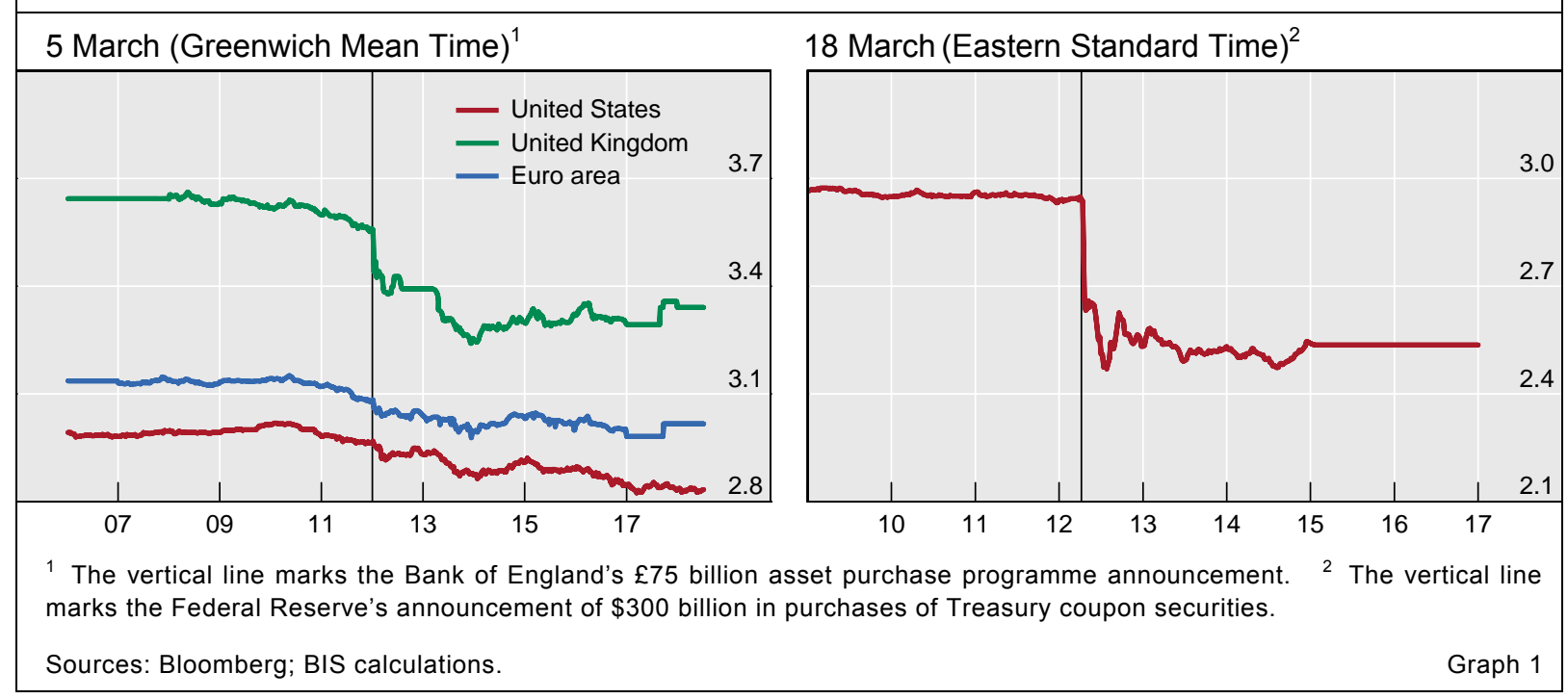


Interaction growing because central banks are mobilising their balance sheets ... $\ldots$ treasury bills and central bank liabilities are becoming close substitutes ... short-term rates, rendering bills and bonds perfect substitutes. The sceptics of this perfection point to the market reactions to the Bank of England's and the Federal Reserve's surprising announcements in March, when yields fell by about 40 basis points in each case (Graph 1). Moreover, bond market anomalies during the financial crisis have heightened doubts about the power of arbitrage and speculation along the yield curve. ${ }^{3}$ To many other observers, however, these market reactions amounted to no more than a spasm of short covering subject to reversal over weeks.

More fundamentally, the scope for interaction has increased in three ways with the extraordinary policy responses to the current financial crisis. First, short-term yields near the zero limit have led central banks to use their balance sheets to affect quantities and yields (BIS (forthcoming, Chapter VI)). As the room for manoeuvre with policy rates shrank, central banks advanced funds and bought assets in size, originally shedding government debt in some cases, but now including government debt. Domestic assets on central bank balance sheets have risen in some cases to double digit percentages of GDP, though still generally well below the government's domestic currency liabilities (Graph 2).

Second, as short-term interest rates approach zero, central bank liabilities and treasury bills become very close substitutes (Ueda (2001)). ${ }^{4}$ As a result, when money yields nothing, central bank purchases of government bonds and the government debt manager's swapping of bills for bonds are "indistinguishable" (King (2004, p 11)). Box 1 traces graphically the similarity in

\section{Gross government debt and central bank assets ${ }^{1}$}

Denominated in domestic currency, as a percentage of GDP in 2008

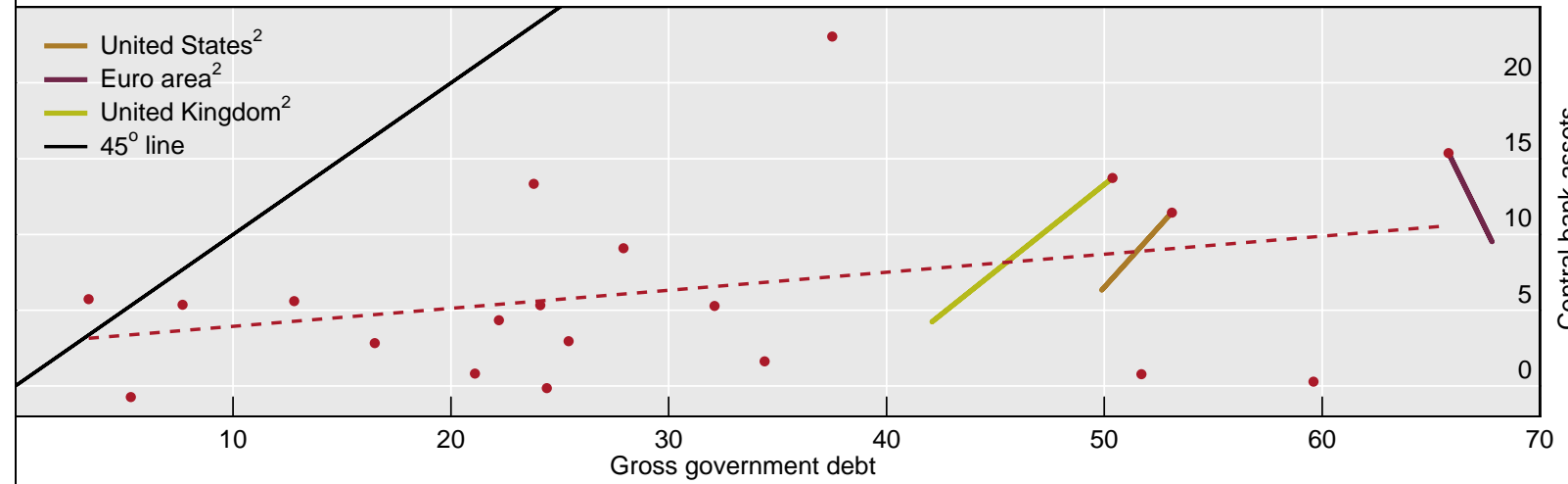

1 Countries represented are Argentina, Australia, Brazil, Chile, China, Chinese Taipei, the euro area, India, Indonesia, Korea, Mexico, the Philippines, Poland, South Africa, Sweden, Switzerland, Thailand, Turkey, the United Kingdom and the United States. For central bank assets, 2007 figures for China; 2006 figures for the Philippines; for the euro area, 2007 figures and total debt instead of government debt. Gross government debt and central bank assets for Japan (not shown) are $180 \%$ and $21 \%$, respectively. 2 The line indicates the change from 2006 to the latest period.

3 Anomalies include the inversion of swap yields below government yields at long maturities, implausible deflation indications from price gaps between benchmark bonds and illiquid inflation-indexed bonds, and the pricing of floating rate notes in the JGB market (see below).

4 Payment of interest on excess reserves or issuance of interest-bearing central bank bills makes central bank liabilities close substitutes for treasury bills even at positive yields. 
terms of balance sheets and holdings of broad money.

Third, the central bank is often urged to take actions that are the province of the debt manager. For instance, Auerbach and Obstfeld (2005) suggest that the central bank reduce the net cost of government debt service by buying bonds at yields stuck at levels well above zero short-term rates. This proposal draws on the long-standing notion that debt management can be used to hedge macroeconomic risks and associated variation in tax receipts and expenditures (Missale (1999)). In particular, reliance on short-term or floating rate debt will save on interest payments if the economy remains weak and subject to deflation, while higher taxes will offset higher interest payments in case of an economic rebound. Such proposals may be well taken or not, but there is no necessary central bank role unless debt management is on autopilot.

In sum, starting from a situation in which monetary and debt management remained in their respective corners, current circumstances have brought them closer. What can we learn from a review of two episodes in which the central bank bought government bonds even as the treasury managed the debt?

\section{US debt management in the early 1930s and Fed bond purchases}

There are two accounts of the monetary policy mistakes of the early 1930s in the United States. They agree that bank deposits (the money supply) should have kept growing, but they differ on how this should have been done.

US monetarists say that the Federal Reserve erred in not buying more Treasury securities in order to increase bank reserves held at the Federal Reserve (Friedman and Schwartz (1963), Meltzer (2002)). Large, sustained Treasury purchases, either bills or bonds, would have pushed short-term interest rates to zero and provided banks with large excess reserves. At some stage, they would have made loans and thereby sustained bank deposits. (In terms of Graph A in Box 1, these US monetarists leave it unclear whether their recommended policy is the top or bottom right-hand panel.)

Others say that the Treasury erred by not supplying bills in exchange for bonds in order to maintain bank assets and thus bank deposits (Culbertson (1957)). After the collapse of share and commodity prices, private borrowers paid down securities credit and non-real estate loans, and banks thereby lost the bulk of their liquid assets. Banks could have replaced these private advances with holdings of Treasury bills, introduced in 1929 (Garbade (2008)). Instead, the Treasury rolled over maturing World War I bonds with new bonds and left a vacuum on bank balance sheets. (In terms of Graph A in Box 1, this account corresponds to the bottom left-hand panel.)

These two arguments agree in their support for increased private sector holdings of highly liquid claims, either excess reserves at the central bank or Treasury bills. They disagree in that the US monetarists see bills and bonds as perfect substitutes, and as a result do not specify whether the Federal Reserve should have purchased (or did purchase) one or the other. To them, bank reserves ("high-powered money") differ from Treasuries, and, in sufficient amounts, eventually lead to credit and broad money growth. On the other side, bills and bonds are considered as different and held in different portfolios so

... and distinctions between the roles of monetary policy and debt management are becoming blurred

Should the Fed have bought Treasuries ...

... or should the Treasury have swapped bills for bonds?

The choice might have had different quantity effects ... 


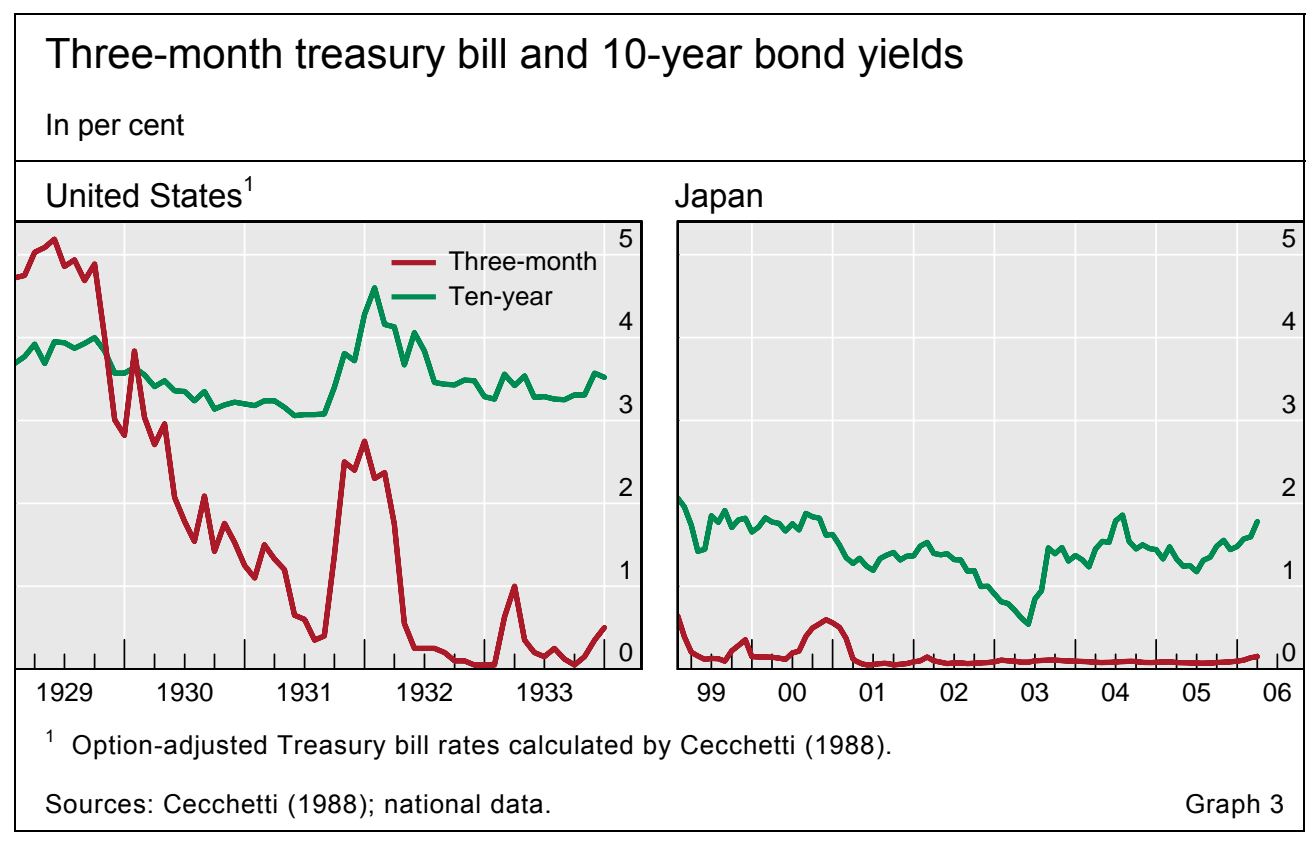

... price effects ...

that a shift toward bills tends to boost broad money growth. In this view, when short-term interest rates are near zero, exchanging excess bank reserves for Treasury bills is seen as not helpful (as in the top right-hand panel of Graph A in Box 1).

In terms of price effects, at least some Federal Reserve officials at the time believed that their buying of Treasury bonds could raise the price and bring down their yields. For instance, in June 1930, Governor Harrison of the Federal Reserve Bank of New York argued to his fellow governors that purchases of Treasury bonds could "lower long-term rates, increase loans to foreigners and thus stimulate exports" (Meltzer (2002, p 307)).

In terms of fiscal effects, if Treasury bills had been substituted for bonds (or the Federal Reserve had bought Treasury bonds in size), the immediate interest savings could have been substantial. It is remarkable how little long-

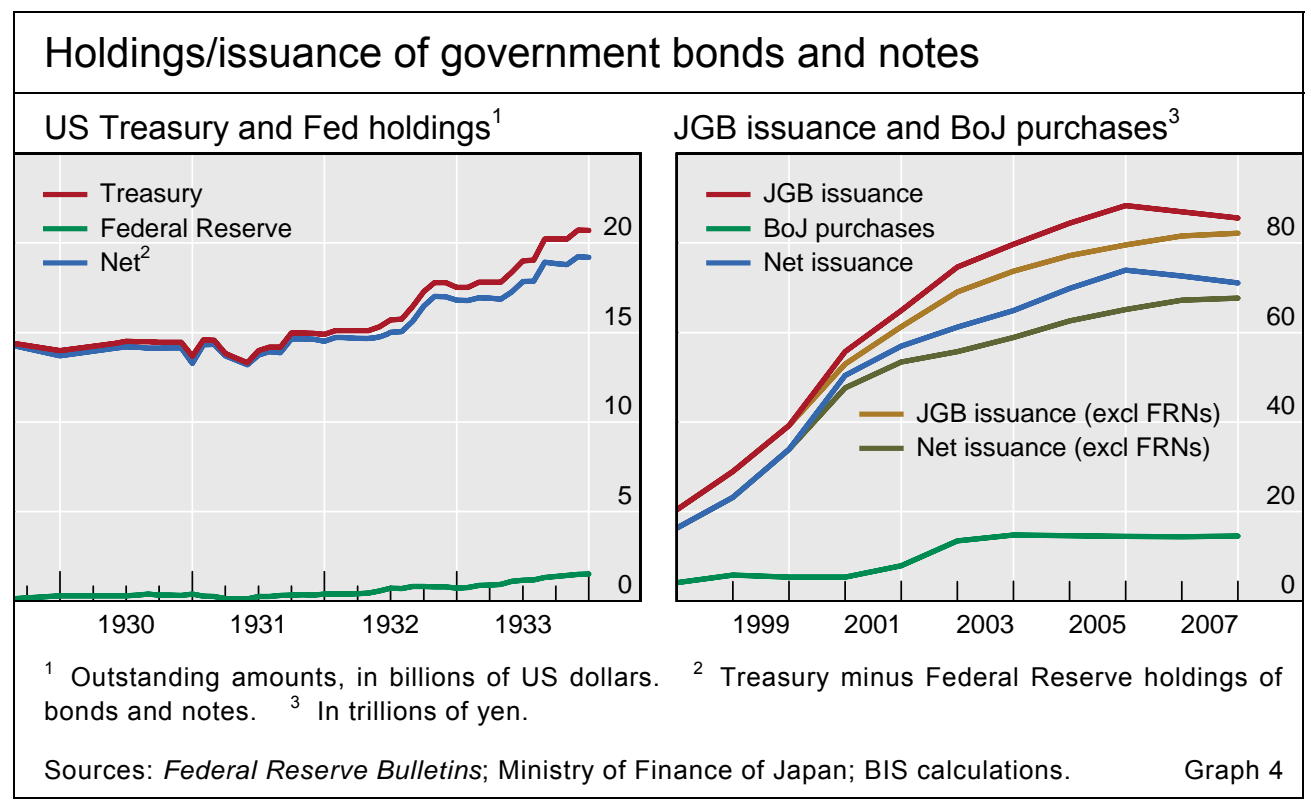




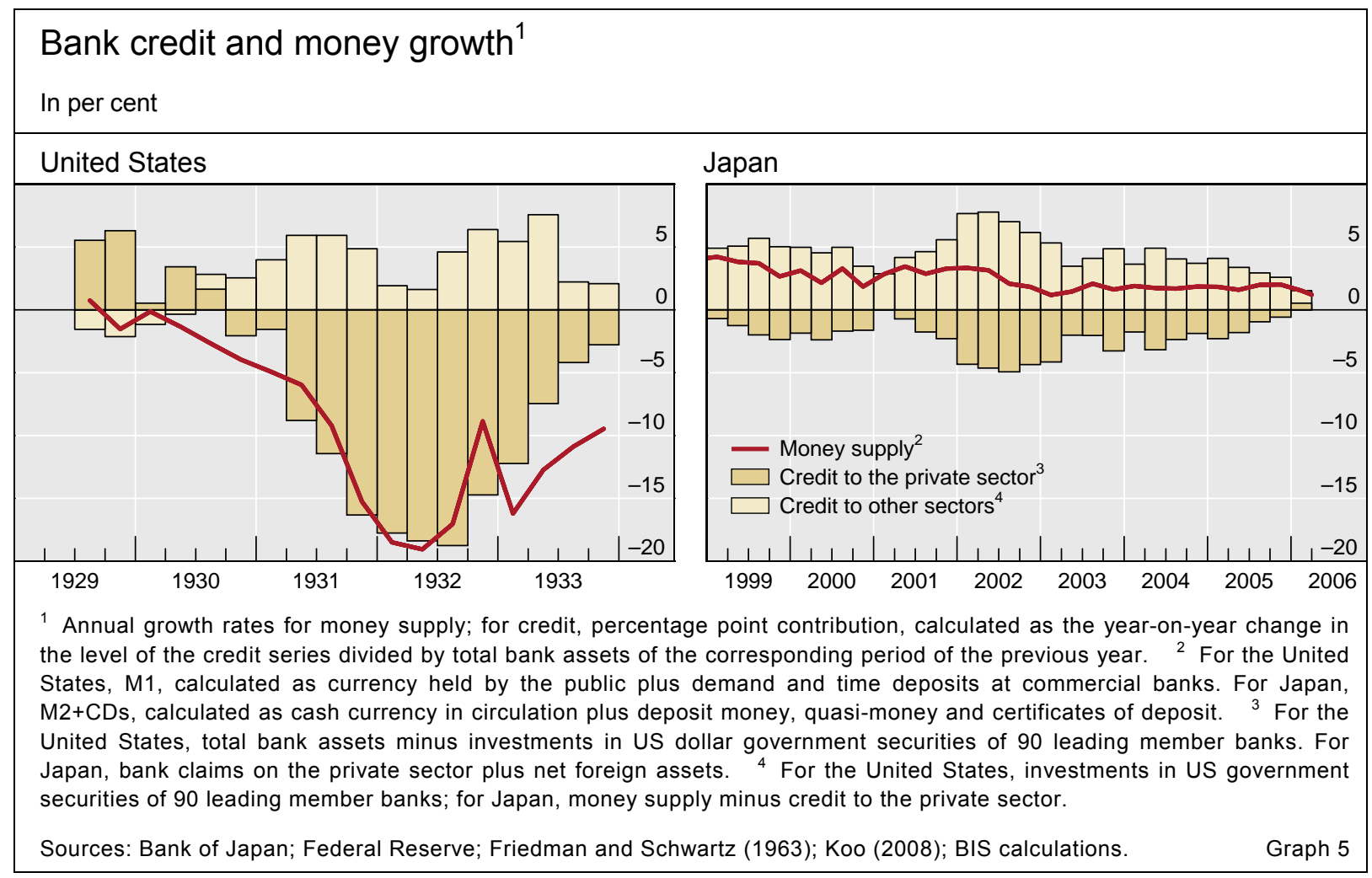

term Treasury yields responded to the decline in Treasury bill rates through the first half of 1931 (Graph 3). Even if Treasury bond yields had not fallen owing to a shift from bonds to bills, interest costs could have been lower.

In the event, Federal Reserve purchases of Treasury securities barely reduced the amounts of bonds held by private investors through 1932 (Graph 4, left-hand panel). In particular, the bond purchases of the summer of 1930 are hardly visible. The Federal Reserve Bulletin reports Treasury debt in millions of dollars, but the Federal Reserve balance sheet in thousands. And except in the summer of 1930, the Federal Reserve generally held more Treasury bills (and certificates) than bonds.

Broad money shrank as the decline in bank credit to private borrowers was not offset by increased holdings of Treasury securities. Even given the lack of an expansive fiscal policy that would have increased the supply of Treasury securities, the Treasury's choice to replace maturing bonds with new bonds failed to provide the banking system with safe and liquid assets. The result, hardly affected by Federal Reserve bond purchases, was that overall assets and bank deposits declined (Graph 5). Such was not the recent experience in Japan, where bank purchases of government securities kept broad money growing.

\section{Japanese debt management since 2000 and BoJ JGB purchases}

At the bottom of the Japanese recession in the early 2000s, there was discussion in some quarters on the possible contribution of debt management to macroeconomic stabilisation. For example, Kuroda (2002), then the Vice Minister of Finance for International Affairs of the Ministry of Finance (MoF),

In the event, little effect of Fed bond purchases on private holdings 
Debt management at zero short-term interest rate mooted ...
... but in the end JGBs issued at longer maturities

Bank of Japan buys government bonds

expressed his view that the scope of debt management could possibly be "widened so as to pursue price stability more explicitly". However, he recognised that this "might mean a compromise with the traditional objective of debt management". The stated general purpose of the MoF's debt management (2008) is to "maintain markets' confidence in the capacity of the government to manage stable issuance of JGBs [Japanese government bonds] and Financing Bills and to repay its outstanding debt". The report's Japanese language version is more pointed: "lowering interest payment cost on JGBs is a serious policy goal". Given this, it might have been difficult to refrain from issuing long at historically very low bond yields, albeit with a potential for tensions with monetary policy.

Some argued in the early 2000s that debt management might contribute to price stability by concentrating issuance at the short end, where yields would be held down by Bank of Japan (BoJ) policy. This would leave less issuance of JGBs at the long end and might allow longer-term bond yields to fall further. At its extreme, such an approach might have meant to "target" bond yields in an attempt to lower them and to stimulate the economy. The idea did not become policy probably because of doubts about the practicality of controlling bond yields by merely changing the composition of debt.

Even in the pursuit of the goal of interest cost minimisation, officials struggled to respond to the environment of near-zero short-term interest rates. This was the case especially after 1999, when the BoJ adopted the so-called zero interest rate policy (ZIRP). Some argued for much larger issuance of financing bills and short-term bonds, while others recognised the rollover and interest rate risks inherent in such a strategy. In the event, they adopted a middle of the road approach. In the MoF's cost-at-risk analysis, an optimal debt issuance structure is determined by the trade-off between cost minimisation and interest rate risks, especially when short-term rates are unusually low (Ministry of Finance of Japan (2008)).

Thus, fiscal years 1999 and 2000 saw a shortening of the maturity of JGBs issued, perhaps in response to the ZIRP (Graph 6, left-hand panel). The next few years (2000-03) seem to have been a period in which the MoF, in an attempt to maintain stable issuance of JGBs in the face of ballooning budget deficits, introduced various new types of debt instruments: 15-year floating rate notes (2000), three-year discount bonds and five-year coupon bonds (2000), and JGBs for individuals and inflation-indexed bonds (2003). These innovations helped to limit the tension with monetary policy. In 2003-04, however, the economy and tax revenue subsequently rebounded and the MoF's attention shifted to medium-term control of interest payments. Hence, the average maturity of issuance lengthened during this period. ${ }^{5}$

When long-term government bond yields began to rise sharply from the end of 1998, some politicians called for the BoJ to revert to the abandoned

5 The MoF has bought back large amounts of existing JGBs using funds from the special account of the Fiscal Investment and Loan Plan since 2002. It has carried out interest rate swap transactions since 2006, in common with many debt managers, which has certainly complicated the relationship between the maturity structure of debt and the yield curve. 


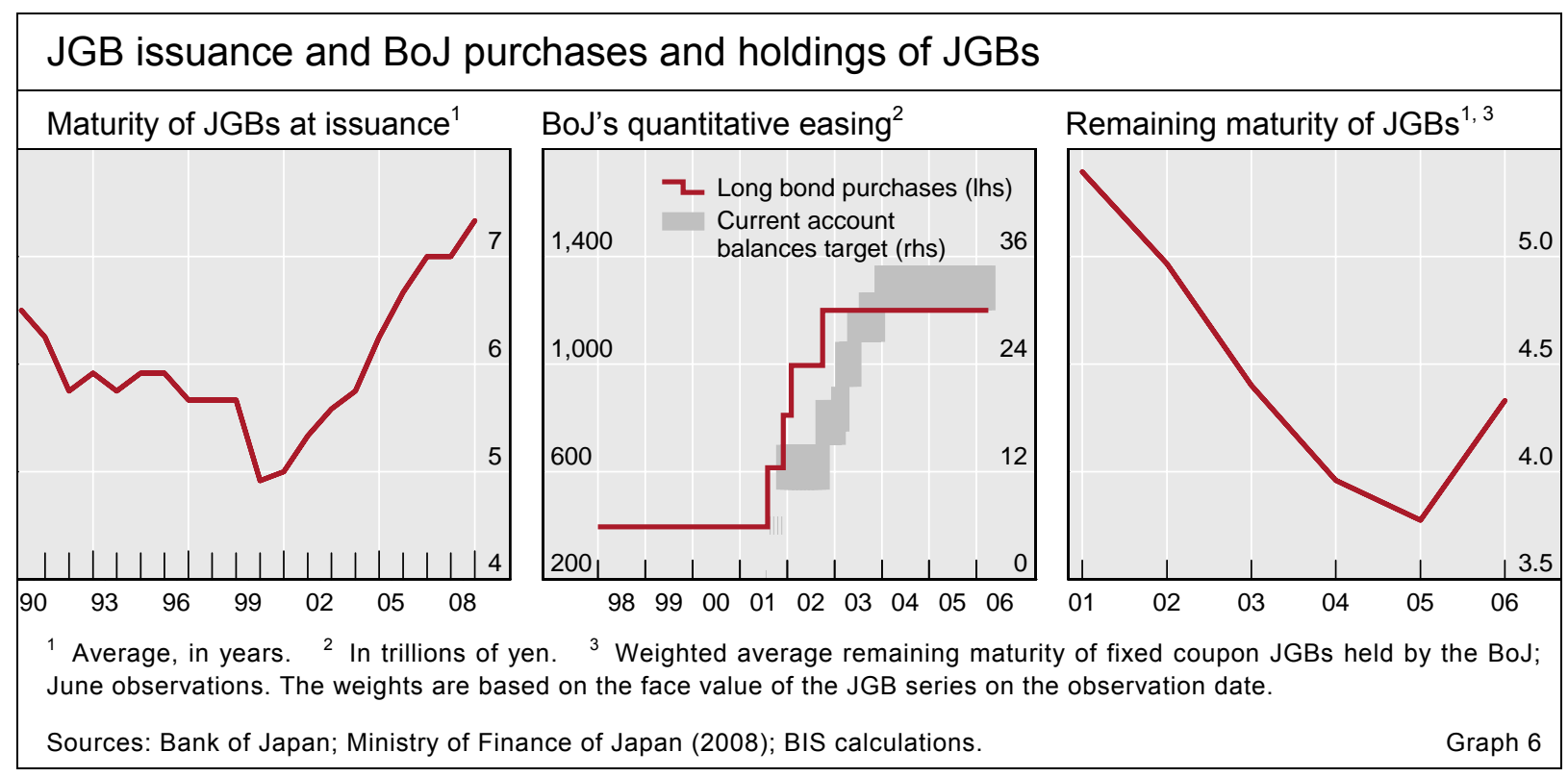

practice of underwriting government bonds (Tomita (2002, p 5)). As a means to achieve the step-ups in current account balances that were at the centre of the its quantitative easing starting in 2001, the BoJ ramped up its monthly outright purchases of JGBs from 400 billion yen to 1.2 trillion yen in four steps over 14 months (Graph 6, centre panel). There was no reference to these purchases' affecting bond yields. In fact, the BoJ set a rule for buying JGBs, which starting in June 2001 included medium-term (two-, four-, five- and six-year) as well as 10-year JGBs, that resulted in its purchase of JGBs of fairly short remaining maturity. ${ }^{6}$ As a result, the remaining maturity of the BoJ portfolio declined from over five years in 2001 to under four years in 2005 (Graph 6, right-hand panel). Broadly, the rule permitted market participants to choose which bonds to discount in price in order to sell to the central bank. In particular, on the day of the bond buying, the BoJ would accept JGBs with the widest gap between the offered yield and the yield curve at the end of the previous day.

In limiting its purchases of government bonds, the BoJ set a maximum at the note issue, which was seen as giving rise to a permanent need to supply funds; up to this limit JGBs could be held to maturity. Outside observers suggested risk management alternatives. Congdon (2003) urged that the government exchange bills for bonds in the market instead of central bank purchases of government bonds, which run the risk of central bank losses from a rise in bond yields. If the central bank were to purchase government bonds, he proposed that the government offer an indemnity against any losses (see UK policy below). When proposals for the BoJ to buy JGBs in quantity were met with the objection that the resulting holdings would risk central bank losses, Bernanke (2003) proposed that the government replace the fixed-rate bonds held by the BoJ with floating rate debt. Implicitly or explicitly, both proposals pointed to debt management.

6 In addition to the change in policy to purchase medium-term bonds, the expectation of persistently low policy rates may also have led to bonds of relatively short remaining maturity being tendered to the BoJ. 


\section{Box 2: Operation Twist revisited}

In the early 1960s, the US economy was thought to need elevated short-term rates to defend the US dollar and lower bond yields to encourage investment. The Federal Reserve engaged in Operation Twist, departing from the earlier bills-only policy to buy Treasury bonds and to sell Treasury bills.

This policy experiment is often thought to have been a failure. In fact, the experiment never happened. The Treasury's extension of maturities overwhelmed the Federal Reserve sale of bills and purchase of bonds (Graph A). "In the four years 1961-64, net purchases outside the 1-year area amounted to only $\$ 6.9$ billion, of which only $\$ 2.3$ billion represented over-5-year maturities. For every dollar of intermediate- and long-term bonds purchased by the System, the Treasury has sold many times that amount" (Beard (1965, p 59)). Moreover, the way that the Federal Reserve bought bonds minimised any impact on rates: "Typically, the Manager did not solicit offerings from dealers, but only purchased some of the intermediate- and long-term securities offered at the dealers' initiative" (ibid, p 60).

As described by Roosa (1963), the Treasury's strategy was to boost issuance of Treasury bills in which central banks then invested their US dollars. At the same time, advance refundings of coupon securities approaching maturity reduced outstanding debt in the "belly" of the curve, ie in the one- to five-year maturities. In current parlance, the Treasury was issuing in "barbell" fashion at three months and beyond five years. It is not clear that studies that related a 10-year Treasury bond yield to a three-month bill rate took proper account of the Treasury strategy.

\section{Residual maturity of US Treasury debt and Federal Reserve holdings of Treasuries ${ }^{1}$}

Average maturity, in months

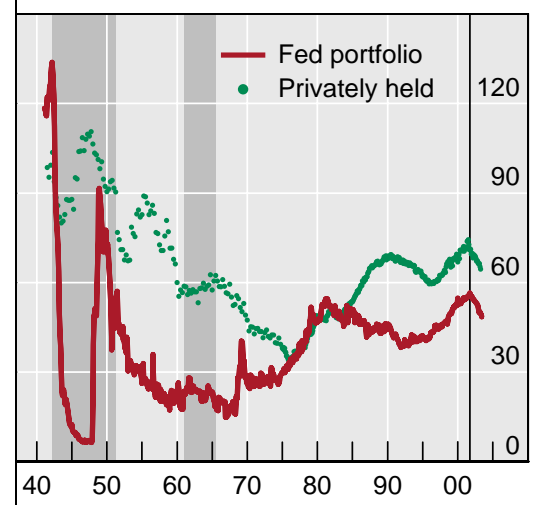

Distribution by maturity of privately held US Treasury debt ${ }^{2,3}$

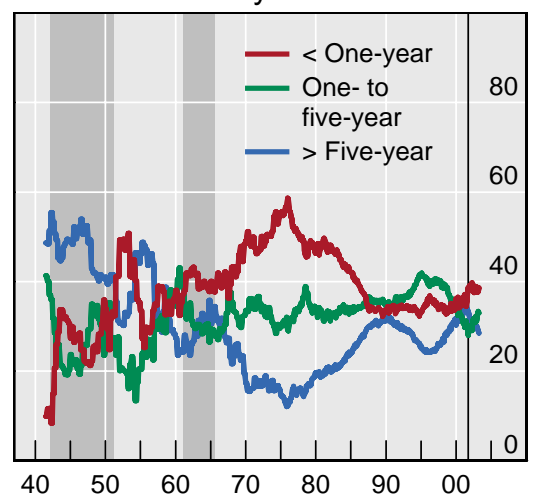

Distribution by maturity of Federal Reserve holdings ${ }^{2}$

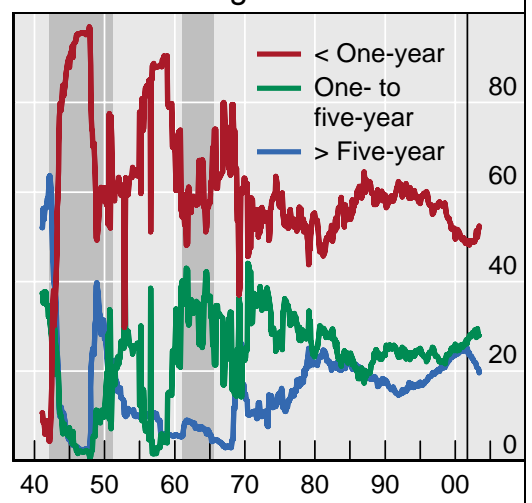

1 The shaded areas indicate World War II and postwar interest rate caps (March 1942-February 1951) and the Operation Twist period (February 1961-June 1965). The vertical line indicates the cancellation of the 30-year bond (October 2001). $\quad 2$ In per cent. 3 Includes foreign central banks.

The growth of JGBs in the hands of other investors slows but does not halt
In the event, how did the step-up in BoJ purchases of Japanese government bonds affect JGB holdings by private parties? First, recall that the central bank stepped up JGB purchases against the backdrop of a lengthening of issuance in 2001 and 2002 by the debt managers (Graph 6). This recalls the experience with Operation Twist in the United States in the 1960s (Box 2).

Second, despite the step-up in central bank purchases, JGB issuance to be absorbed by investors other than the central bank continued to grow. When government issuance is juxtaposed with central bank buying, the net supply of JGBs no more than decelerated owing to the BoJ purchases (Graph 4, righthand panel). The introduction of floating rate notes helped, but did not change the outcome qualitatively (Box 3 ). In retrospect, although attention focused on the central bank purchases of JGBs, issuance policy determined the outcome. 


\section{Box 3: Japanese 15-year floating rate notes}

An important innovation in debt management took place in Japan in this century. Debt managers hesitate to shorten the duration of government debt because it can increase rollover risk. This risk is usually neglected for top-rated sovereigns, but prudent debt managers cannot be indifferent to large financing requirements. Fitch (2009) recently warned that "sizeable and sustained increases in governments' reliance on short-term funding would entail additional risks", recalling the downgrade of Belgium in the 1990s when financing requirements hit a third of GDP.

The Ministry of Finance (MoF) limited such rollover risks by introducing a 15 -year bond (the CMT) in 2000. Its coupon, payable every half year, is set equal to half the average 10-year JGB auction yield over the prior six months less an issue-specific number of basis points (alpha). This ranged from 81 basis points in the first auction, to a peak of over 100 basis points in 2005, to 40-50 basis points in 2007. The floating rate notes reduced the supply of fixed-rate debt significantly (Graph 4, right-hand panel). Nevertheless, like the central bank purchases, issuance of floating rate notes only slowed the growth of issuance of fixed-rate debt.

Since mid-2007, market pricing of these floating rate bonds has fallen below their "theoretical" values, by as much as $10 \%$ in late 2008 , and the MoF cancelled issuance for the balance of the 2008-09 fiscal year. It is said that these bonds had come to be heavily held by hedge funds speculating on a convergence between the market price and the higher theoretical price (Bank of Japan (2008, pp 58-9; 2009, p 45)). The widening of the gap between the market and theoretical price is thought to reflect the recent shrinkage and deleveraging of hedge fund positions.

Views on these purchases' effect on bond yields vary. Baba et al (2005) and Oda and Ueda (2007) find that BoJ purchases had little effect on long-term

Effect on yields debated ... yields. It is hard to distinguish the partial effect of central bank bond purchases from the powerful effect of the central bank's commitment essentially to keep the overnight rate at zero until the return of inflation (the so-called policy duration effect). Bernanke et al (2004, pp 70-1) find that a few surprises (measured, inter alia, by a market participant's forecasts of BoJ bond-buying announcements) had a small but significant effect on JGB yields. Some JGB market participants put weight on the scale of purchases.

Notwithstanding their reliance on JGBs, debt managers' issuance of medium-term bonds sufficed to allow banks to maintain their assets in the face of debt repayment by businesses (Graph 5, right-hand panel). As a result, M2 plus certificates of deposit continued to grow even as the private sector continued to deleverage by paying down bank debt (Shirakawa (2001)). Moreover, because the BoJ commitment to keeping short-term interest rates near zero held down medium- to long-term interest rates, the opportunity cost of not selling more short-term or floating rate debt was limited (Graph 3, righthand panel). On both counts, the recent experience in Japan compares favourably to that of the United States in the early 1930s.

Still, debt management in Japan may have missed opportunities in recent years in leaving much duration to be absorbed by the private sector. The debate over the role that the Bank of Japan could in effect play in debt management may have crowded out a broader debate over the course of debt management more generally.
... but enough medium-term JGB issuance for banks to grow their assets and deposits 
Central banks make similar announcements ...

... with different goals and relationships to debt management

\section{Recent debt management and monetary policy}

In March 2009, the UK, Japanese and US central banks all announced or enlarged programmes to buy government debt. The context for these policies, and the policies themselves, showed some similarities and differences.

In all three cases, huge fiscal deficits and purchases of financial assets require financing. What maturity should the debt have? Apart from a debate in the United Kingdom (eg Booth et al (2008)), discussion of the contribution that debt management might make with interest rates very near zero has been notable by its absence. Instead, the three debt managers seem intent on relying on longer-duration debt, as well rated sovereigns tend to do (Graph 7). To be sure, the US Treasury shortened its debt when it sold bills in late 2008 to help the Federal Reserve sterilise the dollar funding extended to other central banks. However, following legislation allowing the Federal Reserve to pay interest on bank reserves, the US Treasury is stepping up long bond issuance.

Despite the similar timing of the policy changes in March, the goals of the central bank purchases of government bonds and their relationship to debt management show some differences (Table 1). The Bank of England's objectives include both quantity (faster money growth) and price (a lower bond yield) (Dale (2009)). Indeed, the quantitative goal guided the choice of $£ 75$ billion in initial gilt purchases, which amounts to $5 \%$ of broad money (UK House of Commons (2009)). The Bank of Japan's objective is to take the burden off of short-term operations. The Federal Reserve's goal in buying Treasury bonds is "to help improve conditions in private credit markets" (Board of Governors (2009)).

The central bank bond purchases also interacted with debt management in different ways. The Bank of England acted before the Debt Management Office announced its provisional plan of gilt sales for the new fiscal year. The Governor asked for and obtained a promise from the Chancellor that the Office would not alter its plan in the light of central bank decisions on the size, scope and timing of gilt purchases (Bank of England (2009), UK Chancellor of the Exchequer (2009a)). In Japan, the government's large supplementary budget

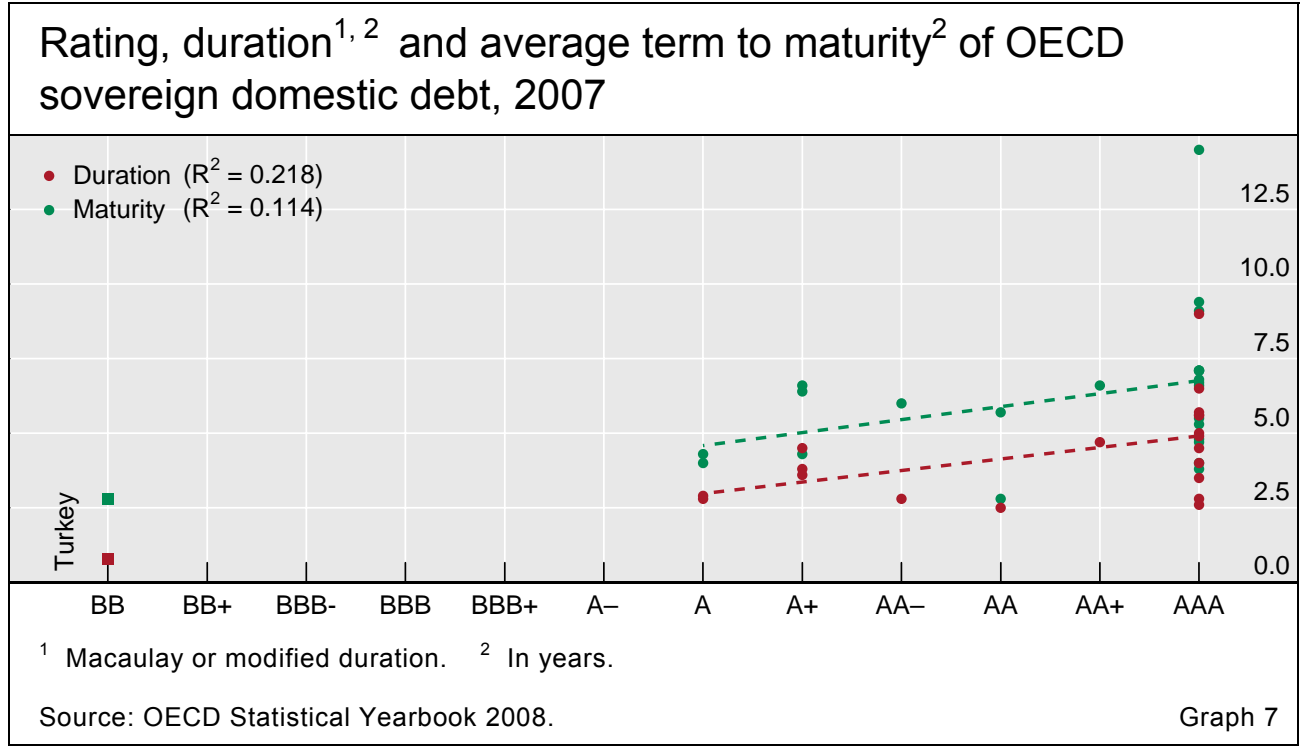




\begin{tabular}{|c|c|c|c|}
\hline \multicolumn{4}{|c|}{ Overview of three central bank policies to buy government bonds, 2009} \\
\hline & Bank of England & Bank of Japan & Federal Reserve \\
\hline Date & 5 March, 7 May & 18 March & \multirow{2}{*}{$\begin{array}{l}18 \text { March } \\
\text { Purchase of } \$ 300 \text { billion in } \\
\text { Treasury bonds over six months, } \\
\$ 92 \text { billion bought as of } 6 \text { May }\end{array}$} \\
\hline Action & $\begin{array}{l}\text { Initial purchase of } £ 75 \text { billion of } \\
\text { gilts and corporates over three } \\
\text { months, to } £ 125 \text { billion in May, } \\
£ 52 \text { billion purchased by } 6 \text { May. }\end{array}$ & $\begin{array}{l}\text { Monthly purchases of JGBs } \\
\text { raised from } ¥ 1.4 \text { to } ¥ 1.8 \text { trillion }\end{array}$ & \\
\hline $\begin{array}{l}\text { Relevant } \\
\text { debt } \\
\text { stock/flow }\end{array}$ & $\begin{array}{l}£ 300 \text { billion outstanding in five- } \\
\text { to } 25 \text {-year bonds as of } 6 \text { May; } \\
\text { issuance of seven- to } 15 \text {-year } \\
\text { gilts in April 2009-March } 2010 \text {, } \\
£ 70 \text { billion }\end{array}$ & $¥ 679$ trillion at end-2007 & $\begin{array}{l}\$ 4.4 \text { trillion Treasury notes and } \\
\text { bonds outstanding on } 30 \text { April; } \\
\text { borrowing for current fiscal year } \\
\text { estimated at } \$ 1.3 \text { trillion }\end{array}$ \\
\hline Rationale & $\begin{array}{l}\text { Boost nominal demand by } \\
\text { increasing broad money (bank } \\
\text { deposits), lowering gilt yields } \\
\text { and improving corporate credit } \\
\text { markets }\end{array}$ & $\begin{array}{l}\text { Take burden off of short-term } \\
\text { operations }\end{array}$ & $\begin{array}{l}\text { Improve the terms of } \\
\text { private credit }\end{array}$ \\
\hline $\begin{array}{l}\text { Market } \\
\text { reaction }\end{array}$ & $\begin{array}{l}40-60 \text { basis points on gilt yield } \\
\text { and } 30 \text { basis points on } \\
\text { corporate } \text { bond } \\
\text { (Dale }(2009))\end{array}$ & $2-3$ basis points & $\begin{array}{l}40 \text { basis point immediate } \\
\text { reaction }\end{array}$ \\
\hline $\begin{array}{l}\text { Risk } \\
\text { manage- } \\
\text { ment }\end{array}$ & $\begin{array}{l}\text { Exchange of letters between } \\
\text { Chancellor and Governor; } \\
\text { indemnity for any Bank of } \\
\text { England losses }\end{array}$ & $\begin{array}{l}\text { JGB holdings by BoJ limited to } \\
\text { note issue; JGBs to be } \\
\text { purchased in specific brackets } \\
\text { of residual maturity to control } \\
\text { the maturity of BoJ's portfolio }\end{array}$ & $\begin{array}{l}\text { No reference in Board of } \\
\text { Governors }(2009 b)\end{array}$ \\
\hline \multicolumn{4}{|c|}{ Sources: UK Debt Management Office (2009); US Treasury (2009); Bank of England; Bank of Japan: Federal Reserve. $\quad$ Table 1} \\
\hline
\end{tabular}

for 2009 implies an issuance of about 17 trillion yen of JGBs in addition to the amount already planned in the initial budget. This is expected to shift the focus of debt management policy back towards the goal of stable issuance of JGBs. The Bank of Japan has not referred to any interaction with the government's debt plan in its own announcements. Similarly, the Federal Reserve, acting after the first Treasury refunding announcement in the first days of the new administration, made no reference to the government's funding plan.

\section{Conclusions and prospects}

Government debt management may have a role to play amid private deleveraging and very low policy rates. Some observers emphasise the potential to lower bond yields by swapping treasury bills for bonds in private hands, reinforcing the effect on bond yields of the prospect of sustained low policy rates. Monetarists emphasise that ample issuance of short- and mediumterm government debt (including state-guaranteed bank debt) would allow banks to maintain deposit growth even as households and firms pay down their debt. Widespread deleveraging of financial firms' balance sheets may strengthen either argument. Despite the expansion of some central bank balance sheets, treasuries continue to enjoy more scope to alter the weight of bills and bonds held by private investors. For now, treasuries can issue longterm debt with interest rates tied to short-term bill rates in the confidence that monetary policy will keep bill yields low. In doing so, treasuries stand to benefit from interest cost savings as long as short-term rates remain low. When 
economic activity quickens and interest rates rise again, they stand to benefit from higher taxes in compensation for higher debt servicing costs.

\section{References}

Auerbach, A J and M Obstfeld (2005): "The case for open-market purchases in a liquidity trap", American Economic Review, no 95, vol 1, pp 110-37.

Baba, N, S Nishioka, N Oda, M Shirakawa, K Ueda and H Ugai (2005): "Japan's deflation, problems in the banking system and monetary policy", BIS Working Papers, no 188.

Bank of England (2009): Letter from the Governor to the Chancellor of the Exchequer, 17 February.

Bank for International Settlements (forthcoming): 79th Annual Report, June.

Bank of Japan (2008, 2009): Financial markets report, September and March.

Beard, T (1965): US Treasury advance refunding, Federal Reserve Board.

Bernanke, B (2003): "Some thoughts on monetary policy in Japan", remarks to the Japan Society for Monetary Economics, 31 May.

Bernanke, B, V Reinhart and B Sack (2004): "Monetary policy alternatives at the zero bound: an empirical assessment", Brookings papers on economic activity, vol 94, no 2, pp 1-78.

Bleijer, M (1999): "Public debt management and monetary policy: macroeconomic and institutional interactions", in European Union accession, World Bank, pp 62-9.

Board of Governors of the Federal Reserve System (2009a): Federal Open Market Committee press release, 18 March.

(2009b): "The role of the Federal Reserve in preserving financial and monetary stability", 23 March.

Booth, B, T Congdon, C Goodhart, J Greenwood, M Oliver, G Pepper, D Smith and S Ward (2008): "Government must borrow from banks to create money", Financial Times, 31 December.

Cecchetti, S G (1988): "The case of the negative nominal interest rates: new estimates of the term structure of interest rates during the Great Depression", Journal of Political Economy, vol 96, no 6, December.

Clouse, J, D Henderson, A Orphanides, D Small and P Tinsley (2003): "Monetary policy when the nominal short-term interest rate is zero", Topics in macroeconomics, vol 3, no 1.

Congdon, T (2003): "Debt management and deflation 1", and "Debt management and deflation 2", Lombard Street Research, Monthly Economic Review, nos 165 and 166, March, pp 2-19, and April, pp 2-23.

Culbertson, J (1957): "The term structure of interest rates", Quarterly Journal of Economics, vol 71, no 4, November, pp 485-517. 
Dale, S (2009): "Tough times, unconventional measures", speech to the Association of British Insurers Economics and Research Conference, London, 27 March.

Fitch Ratings (2009): "Sovereigns: European government borrowing", International Special Report, 26 January.

Friedman, M and A Schwartz (1963): A monetary history of the United States, 1867-1960, University of Princeton Press.

Garbade, K (2007): "The emergence of 'regular and predictable' as a Treasury debt management strategy”, Economic Policy Review, vol 13, no 1, March.

(2008): "Why the US Treasury began auctioning Treasury bills in 1929", Economic Policy Review, vol 14, no 1, July.

Kalderen, L and H Blommestein (2002): "The role and structure of debt management offices", Debt management and government securities markets in the 21st Century, pp 101-33.

King, M (2004): "The institutions of monetary policy", American Economic Review, vol 94, no 2, May, pp 1-13.

(2009): "Interview with Stephanie Flaunders of the BBC", 5 March.

Koo, R (2008): The holy grail of macroeconomics: lessons from Japan's great recession, Wiley.

Kuroda, H (2002): "Open market operations, debt management and exchange market intervention: the general case and the Japanese case", speech to the Japan Project Meeting organised by NBER/CEPR/CIRJE/EIJS, 13 September.

Kuttner, K (2006): "Can central banks target bond prices?", NBER Working Papers, no 12454, August.

Meltzer, A (2002): History of the Federal Reserve, vol I: 1913-51, University of Chicago Press.

Ministry of Finance of Japan, Finance Bureau (2004-08): Debt management report.

Missale, A (1999): Public Debt Management, Oxford University Press.

Oda, N and K Ueda (2007): "The effects of the Bank of Japan's zero interest rate commitment and quantitative monetary easing on the yield curve: a macrofinance approach", The Japanese Economic Review, vol 58, no 3, September, pp 303-28.

Roosa, R (1963): "The management of the national debt", lecture to the Industrial College of the Armed Forces, Washington DC, 31 October.

Shirakawa, M (2001): "Monetary policy under the zero interest rate constraint and balance sheet adjustment", International Finance, vol 4, pp 463-89.

Tomita, T (2002): "The need for redefining Japan's government debt policy", NRI Papers, no 42, 1 February. 
Ueda, K (2001): "Japan's liquidity trap and monetary policy", speech to the Japan Society of Monetary Economics, Fukushima University, 29 September.

UK Chancellor of the Exchequer (2009): Letter to the Governor of the Bank of England, 3 March.

UK Debt Management Office (2009): Debt and reserves management report 2009-10, April.

UK House of Commons, Treasury Committee (2009): February Inflation Report: Evidence, 24 March (uncorrected text).

US Treasury Office of Debt Management (2009): "Quarterly refunding charts", 27 April. 